\title{
A Piece of a Puzzle of Haplotypes for the Indian Ocean Hawksbill Turtle
}

\author{
Rita Anastácio, Mário Jorge Pereira \\ Departamento de Biologia e CESAM, Universidade de Aveiro, Aveiro, Portugal \\ Email:rita_sofia@msn.com
}

How to cite this paper: Anastácio, R. and Pereira, M.J. (2017) A Piece of a Puzzle of Haplotypes for the Indian Ocean Hawksbill Turtle. Natural Resources, 8, 548-558. https://doi.org/10.4236/nr.2017.88034

Received: July 8, 2017

Accepted: July 31, 2017

Published: August 3, 2017

Copyright $\odot 2017$ by authors and Scientific Research Publishing Inc. This work is licensed under the Creative Commons Attribution International License (CC BY 4.0).

http://creativecommons.org/licenses/by/4.0/

\begin{abstract}
The Indian Ocean basin has much to reveal in what concerns marine turtles. Its regional management units (RMUs) are still lacking molecular data to define conservation strategies and priorities. Vamizi Island is one of the best known rookeries in the north of the Mozambique Channel. A mitochondrial DNA analysis revealed 14 haplotypes for the hawksbill turtle's nesting and foraging in/near Vamizi, twelve of which were new in 2011. Though more studies inside the Channel are needed, Vamizi Island possibly contributes with hatchlings for other locations. More knowledge is important to define priorities for management units inside the Indian Ocean.
\end{abstract}

\section{Keywords}

Eretmochelys imbricata, mtDNA, Haplotype, Regional Management Unit, Mozambique Channel

\section{Introduction}

Genetic studies allowed [1] the definition of 58 regional management units (RMUs) around the globe, for the seven marine turtle species. The RMUs constitute areas of assessment, since they identify important geographic areas for marine turtle's populations according to indicators like presence, density, and richness [2]. The extinction of an entire RMU, or its fragmentation, represents the disruption of species' ecological roles [2]. For Eretmochelys imbricata, known as hawksbill turtle, 13 RMUs were identified (though 7 are putative RMUs), and some of these, like the Indian-Southeast RMU, are lacking solid data [2]. Data gathered in nesting, foraging or even migrating areas for long-term studies, are essential, since marine turtles are long-lived species, and to recognize patterns and tendencies, and make analysis about the causes of changes in pop- 
ulation structure and behavior [3]. The Seychelles in the Western Indian Ocean (WIO) have a long record of nesting populations for the hawksbill turtles, which have been protected there since the 1970s [4]. The species uses the Mozambique Channel (MZC) as a migratory route [5], and occurs in many places of and near it: Saya de Malha/Banks (feeding grounds), Eparses Islands (Juan de Nova with more than 50 nesting females/year), Mayotte (up to 100 nesting females/year), Reunion Island, Madagascar (nesting grounds), Tanzania (Mnazi Bay, Mafia Island nesting and feeding grounds), and Mozambique (Quirimbas Archipelago) [5] [6]. Vamizi $\left(11^{\circ} 01^{\prime} 22.4^{\prime \prime} \mathrm{S}, 40^{\circ} 41^{\prime} 32.8^{\prime \prime} \mathrm{E}\right)$ is one of the many coralline islands belonging to the Quirimbas Archipelago, exhibiting healthy and well preserved corals [7]. It is one of the north MZ well-known turtle's rookeries. But, marine turtle's conservation programs are still concentrated in the south of MZ, in detriment of central and northern parts of the coastline [8]. With such a vast coastline inside the MZC, and with 5 species nesting or feeding in the area, a greater effort to gather more data is expected. Vamizi's nesting turtle monitoring program began in 2002, and has gathered information on green [7] [9] and hawksbill reproduction parameters [7] [10]. The conservation program also provided insight on the coral richness and fishery pressures [11] that also affect turtles near the island [7]. Anthropogenic activity can also contribute to disturb turtles' nesting activity [9] and impose risks near rookeries or during oceanic migrations [6]. But, though assessments of nesting activities in beaches are important, much is still needed to understand marine turtles' dispersion patterns and behavior in the south WIO, especially in what regards Mozambique's coast [8]. This is a challenging task due to the complexity and high variability of the MZC water mechanisms [12], but also due to the lack of understanding in what regards marine turtles' behavior in the ocean (in [13], see question no. 2.2., one of the 20 meta questions relating to sea turtle research and conservation). Oceanic currents in the WIO indicate a complex system still difficult to unfold, but the complexity inside the MZC is also under study [14]. Inside the MZC, the water circulation is highly variable and eddy driven [12]. The MZC eddies have a strong impact on biota [12] with implications on food-webs [5]. [12] hypothesizes that "the frontal zones between mesoscale eddies, and the associated interstitial waters of the turbulence field, create pathways for biological distribution that link the shelf regions, islands and atolls of the Mozambique Channel", all explored territories by marine turtles [15]. The study of the pathways linking these areas could help to understand marine animals' use of the channel (e.g. how hawksbill adults move and forage inside the channel during the nesting season), and, by consequence, their distribution inside it.

Water movements may also have an impact on the distribution of young hatchlings [16] [17] though new insights are being given by recent studies [18]. Eddies may be too slow as effective transport vectors of young turtles (1 - 2 year old), which are active (oriented) swimmers in contrast to what was believed (passive swimmers that were dragged) [18]. Due to the difficulties in marking 
(and recapturing) hatchlings and juveniles, or studying the currents, one alternative for understanding turtles' distribution is by sampling individuals (in foraging and nesting grounds) and sequencing their DNA.

Maternally inherited mitochondrial DNA (mtDNA) studies give insight about the provenience of each turtle (where it was born), even when applied to groups of juveniles [19]. The identification of different haplotypes by these studies, enables the definition of populations' genetic structure and phylogeography, and the comprehension of fidelity behavior to nesting and feeding grounds [20]. Haplotypes work as "genetic tags" [21], especially in what concerns the definition of nesting populations as management units (MUs) [1] [19]. Genetic tags can be used to understand how diversified a rookery is, and to what extent it is important to manage the area around it [21].

Five of the RMUs of the Indian Ocean (mostly in the East) are classified as high risk-high threat (HR-HT) areas, and the Indian Ocean Basin has the lowest availability and quality data concerning marine turtles [2]. Many of the Indian Ocean countries are called to provide more data on their sea turtle populations, not only to define RMUs more accurately [2], but also to fulfill the CBD goal of halting biodiversity loss. The sequencing of the mitochondrial DNA (mtDNA) control region [22] of samples from hawksbill turtles from Vamizi Island adds information for the Indian Southwest RMU characterization. But it enhances the debate around the connections between Indian Ocean's rookeries and the seaways turtles use in our time, or used in the past of Earth's recent history.

\section{Discussion}

The Cenozoic marine turtles lineage [23] endured many climate transformations [24]. Their resilience is shown by their non-extinction through the changes in two completely different oceanic systems: the Pliocene and the Pleistocene oceans [25]. From the warmer than today's Pliocene oceans to the cold global climate of the Pleistocene (with glacial and interglacial variations), one can hypothesize marine turtles being confined to southern oceans from the beginning of the Ice Age until the last maximum ice coverage episode. During the Pleistocene Epoch, climatic zones changed (northern and eastern Africa were fertile in consequence of abundant rainfall) [23] but, also, sea level may have dropped more than 100 meters [23], due to the enormous quantities of the planet's surface water added to northern glaciers [26], changing coastlines in various ways [27]. Oceanic currents changed [25] and so did migratory seaways [26] and nesting territories. Were southern Pleistocene oceans full of marine turtles, competing for space and food, whereas northern hemisphere oceans were depleted of these animals? Though many doubts persist, our current knowledge from oceanic changes has the advantage of corroborating [28] views about turtles' adaptation capacity during changes in sea level rise, nesting sites erosion and modification, and changes in migratory pathways. Human activities have been representing a challenge for marine turtles during the Holocene [16]. When investigators are still lacking knowledge about turtles' behavior [13], how 
will they manage conservation programs to undo the effects of pollution and bycatch, for example? What do haplotypes reveal? Are marine turtles predictable, when researchers try to understand their past?

Haplotype diversity studies revealed, for example, that natal homing, though "strong", is "imperfect" among females [19], and, in fact "breeding populations may encompass several proximal nesting sites" [29]. Before attaining the reproduction stage, young marine turtles of different rookeries mix in the ocean [19] [29]. But when females have to nest they choose a specific site (or nearby site) [16] [19]. This means that on those sites a prevalent maternal inherited structure of the nesting populations and their hatchlings exists and prevails for long periods of time (if the rookery does not become extinct) [19]. The number and variety of haplotypes exhibited by a rookery is its "banner" [21].

For Testudines, that appeared in the Late Triassic [30], the mean microevolutionary rate for mtDNA, which is lower when compared with other vertebrates [31], is used to build up matrilineal haplotype trees showing sequence divergence estimates in the geologic timescale [31]. Alterations on haplotype frequencies on a nesting beach are of conservation concern; but knowing the causes implies completely understanding the RMU to which that rookery belongs, which for the WIO is still difficult. This exercise can be done with the published papers about the haplotypes discovered so far (see [32]). We tried to make the same exercise starting with haplotypes from Vamizi. Hawksbill turtles collected in Vamizi revealed 14 haplotypes, from which two were already discovered, Ei_15 and EIJ4 haplotypes, and 12 were new [22] (isolates number 49, 60, 65, 73, 95, 97, $101,102,104,113,114$, and 128 [10]), being introduced in 2011 in the GenBank database accession numbers JF926554.1, JF926544.1, JF926553.1, JF926547.1, JF926546.1, JF926545.1, JF926548.1, JF926549.1, JF926550.1, JF926555.1, JF926551.1, and JF926552.1, respectively [22].

\subsection{Connection of the WIO with the Indo-Pacific Haplotypes}

The detected common haplotypes that linked the WIO with the southern Indian ocean (SEIO) are the Ei_15 haplotype, occurring in Vamizi [22] and in Southeast Asia [33], and the EiJ4 haplotype, occurring in Vamizi [22], in Southeast Asia [34], and in the Pacific Ocean, Japan [35]. In the SEIO Malaysian rookeries and foraging aggregations, the 20 haplotypes described [34] reveal connections not only with the WIO, but also with the Pacific and Northeast Indian populations [34]. In fact, the haplotype phylogenetic connections made [35] postulate that hawksbill turtles suffered an expansion after the last glacial maximum, during the Pleistocene. Considering that evidence suggests a slowdown in mean microevolutionary rate for turtle mtDNA [31] [36], it is expected that the link between the actual Indian and Pacific ocean populations will be clarified, since it is preserved in the form of an ancestral identity-tag. But these are only assumptions. [35], following [37] [38] and [39], suggested that hawksbill and green turtles populations suffered late-Pleistocene expansions from nesting and foraging equatorial regions to higher latitudes, hypothetically due to climate and sea-level 
fluctuations. That expansion occurred "from multiple sources following a bottleneck" [39] [40] in [35]. [41] goes further, postulating that the radiation of turtles began in the Indian Ocean, and developed into the Pacific and the Atlantic Oceans. Even though [36] emphasize that "divergence dates as old as $5.63 \mathrm{Mil}$ lion years", Miocene epoch (23.7 - 5.3 Mya), "are needed to explain geographic genetic variation in E. imbricata", haplotype distribution conjugated with slow mutation rates might explain why recent populations retain ancient molecular sequences from different and geographically separated rookeries.

There is no doubt that both haplotypes Ei_15 and Eij4 link the Pacific and Eastern Indian populations with the WIO populations. Still, more data will bring insight, especially the analysis on the connections between the Arabian/Persian Gulf and the Red Sea rookeries and foraging sites, where important concentrations of hawksbills are found [42] [43], and the MZC populations with other Indo-Pacific rookeries and foraging grounds [32]. The Persian hawksbill subpopulation mtDNA analysis revealed endemism, with seven specific haplotypes discovered so far [44] [45]. The Persian haplotypes are related with haplotypes from the Southeast Asian Region (Ei_1, and Ei_6 haplotypes, submitted by [46], after a study for the Department of Fisheries Malaysia), as emphasized by [45].

\subsection{Connection of the WIO with the Eastern Atlantic Haplotypes}

With the purpose of giving insight into population connectivity among Ascension Island turtles, and the ones from other parts of the globe, [47] used a paired approach. With genetic analysis and dispersal simulations they identified possible sources for juvenile hawksbill populations from the Atlantic island, where it is known that they do not nest. Their analysis showed that Vamizi's haplotype 113 belongs, alongside the identical sequences Okayama 24-Seychelles FG, EiA48, and EATL (found in Cape Verde Islands FGs and Principe Island nesting females), to the Clade "Western Indian Ocean foraging grounds (FGs) and Eastern Atlantic nesting and FGs" [47]. The same study showed that Vamizi's haplotype 104 belongs to the "Indo-Pacific nesting and FGs" Clade [47]. These results corroborate [41]'s hypothesis of the Indian Ocean being the source of expansion of marine turtles.

Other questions are being posed, such as: is there a connection between Indian and Atlantic Ocean basins nowadays? Are hatchlings from the north of MZC being driven by currents towards the Eastern Atlantic Ocean? Is the Indian Ocean serving as "a source of at least a small portion of hawksbill juveniles in the Atlantic basin" from locations as far as Seychelles [47] or Vamizi? Or, are these genetic connections resulting only from past migrations that, alongside with slow mtDNA mutation rates conserved Indian haplotypes in the south Atlantic populations?

We are inclined to think that the hypothesis of connections between different ocean basins nowadays is less likely; hence, the second hypothesis, i.e. past migrations and slow mutation rates, is more likely to explain the haplotype distribution [29] [31]. Like [17] emphasize, "because nesting aggregations in eastern 
Atlantic exhibit EATL haplotypes, the presence of this "typical" Indo-Pacific haplogroup in Atlantic areas does not necessarily mean that E. imbricata individuals are currently migrating among oceans". This discussion is used to explain the provenience of the São Tomé e Príncipe nesting and foraging hawksbill's populations [48], since the EATL haplotype is so abundant in these rookeries, whereas it is less abundant in other Atlantic locations revealing a strong past connection with the WIO. But the connection between East Atlantic EATL and the WIO identical haplotypes will only be clarified with more studies (molecular, telemetry, nesting monitoring) in other locations, especially from the MZC [48].

\subsection{Haplotype and Nucleotide Diversities}

Finally, the importance of the north MZC rookeries is emphasized by the haplotype diversity values in Vamizi Island. The highest value for haplotype diversity (h) is $0.8950 \pm 0.0020$ for Vamizi. The highest nucleotide diversity $(\pi)$ is 0.0743 \pm 0.0021 (Santos, personal communication). Haplotype diversities described for the Atlantic Ocean (Ascension Island) are $h=0.333 \pm 0.124$ for juveniles [47], for Brazil $h=0.358 \pm 0.069$ [49], and for the Cayman Islands (Caribbean) $h=$ $0.72 \pm 0.04$ for a mixed-stock foraging juveniles [21]. The 32 samples (embryos) collected in the Kish and Qeshm Islands in the Persian Gulf revealed five endemic haplotypes with values of $h=0.69$ and $\pi=1.56$ [44]. For feeding populations in Yaeyama Islands in Japan, eleven haplotypes were found, for which $\mathrm{h}=$ 0.783 , and $\pi=0.018$ [35]. All these results corroborate that Vamizi's rookery, and most likely other locations inside and near the MZC, is genetically important for conservation, with high haplotype and nucleotide diversities.

\section{Conclusion}

The WIO puzzle concerning the genetic variation of hawksbill turtles and the connection with other oceans is still unsolved. More research in the Indian Ocean is demanded, to enlarge the conservation effort and to comprehend which spots must be connected in the migratory pathways of marine turtles. In what concerns the MZC particularly as a source of information to understand the mechanisms that explain current distribution of haplotypes between different ocean basins, more molecular studies will bring more certainties. The establishment of protected corridors inside the MZC is crucial, due to the connectivity that it exhibits for its biota [12]. More protected MUs in the continental shelf regions of Madagascar and Mozambique, with new monitoring programs for foraging and nesting grounds, are also needed. Mozambique is reported as having less than 10 females/year [43], when [10] reported 34 emergences for the 2003 nesting season in Vamizi alone. This last example shows the need for more reporting, since Mozambique is thought to have a bigger population for nesting hawksbills. The fact is that it is urgent to ensure the maintenance of pristine habitats inside the MZC that nurtures a vast genetic richness, not only to recover the densities of marine turtles in these locations, but because turtles have signif- 
icant economic value that can be managed to alleviate poverty. While researchers are trying to solve many questions concerning marine turtle's adaptation and distribution patterns, human activities still strongly jeopardize populations and their own well-being. The future of marine turtles depends on the ability of conservationists and governments to actively engage poor people in the management of wild life.

\section{Conflict of Interest}

Authors declare that they have no conflict of interest.

\section{References}

[1] Wallace, B.P., DiMatteo, A.D., Hurley, B.J., Finkbeiner, E.M., Bolten, A.B., Chaloupka, M.Y., Hutchinson, B.J., Abreu-Grobois, F.A., Amorocho, D., Bjorndal, K.A., Bourjea, J., Bowen, B.W., Dueñas, R.B., Casale, P., Choudhury, B.C., Costa, A., Dutton, P.H., Fallabrino, A., Girard, A., Girondot, M., Godfrey, M.H., Hamann, M., López-Mendilaharsu, M., Marcovaldi, M.A., Mortimer, J.A., Musick, J.A., Nel, R., Pilcher, N.J., Seminoff, J.A., Troëng, S., Witherington, B. and Mast, R.B. (2010) Regional Management Units for Marine Turtles: A Novel Framework for Prioritizing Conservation and Research across Multiple Scales. PLoS ONE, 5, e15465. https://doi.org/10.1371/journal.pone.0015465

[2] Wallace, B.P., DiMatteo, A.D., Bolten, A.B., Chaloupka, M.Y., Hutchinson, B.J., Abreu-Grobois, F.A., Mortimer, J.A., Seminoff, J.A., Amorocho, D., Bjorndal, K.A., Bourjea, J., Bowen, B.W., Dueñas, R.B., Casale, P., Choudhury, B.C., Costa, A., Dutton, P.H., Fallabrino, A., Finkbeiner, E.M., Girard, A., Girondot, M., Hamann, M., Hurley, B.J., López-Mendilaharsu, M., Marcovaldi, M.A., Musick, J.A., Nel, R., Pilcher, N.J., Troëng, S., Witherington, B. and Mast, R.B. (2011) Global Conservation Priorities for Marine Turtles. PLoS ONE, 6, e24510.

https://doi.org/10.1371/journal.pone.0024510

[3] Eckert, K.L., Bjorndal, K.A., Abreu-Grobois, F.A. and Donnelly, M., Eds. (1999) Research and Management Techniques for the Conservation of Sea Turtles. No. 4, IUCN/Species Survival Commission Marine Turtles Specialist Group Publication, Washington DC.

[4] Mortimer, J.A. and Donnelly, M. (IUCN SSC Marine Turtle Specialist Group) (2008) Eretmochelys imbricata. The IUCN Red List of Threatened Species. Version 2014.2. Downloaded on 12 August 2014. http://www.iucnredlist.org/

[5] Obura, D.O., Church, J.E. and Gabrié, C. (2012) Assessing Marine World Heritage from an Ecosystem Perspective: The Western Indian Ocean. World Heritage Centre, United Nations Education, Science and Cultural Organization (UNESCO), p. 124.

[6] Bourjea, J., Nel, R., Jiddawi, N.S., Koonjul, M.S. and Bianchi, G. (2008) Sea Turtle Bycatch in the West Indian Oceans: Review, Recommendations and Research Priorities. Western Indian Ocean Journal of Marine Science, 7, 137-150.

[7] Garnier, J., Hill, N., Guissamulo, A., Silva, I., Witt, M. and Godley, B. (2012) Status and Community-Based Conservation of Marine Turtles in the Northern Querimbas Islands (Mozambique). Oryx, 46, 359-367.

https://doi.org/10.1017/S0030605311001566

[8] Louro, C.M.M., Pereira, M.A.M. and Costa, A.C.D. (2006) Report on the Conservation Status of Marine Turtles in Mozambique. Publisher República De Moçam- 
bique, Ministério Para A Coordenação Da Acção Ambiental, Centro de Desenvolvimento Sustentável para as Zonas Costeiras. 40 p, IOTC-2011-WPEB07-INF27.

[9] Anastácio, R., Santos, C., Lopes, C., Moreira, H., Souto, L., Ferrão, J., Garnier, J. and Pereira, M.J. (2014) Reproductive Biology and Genetic Diversity of the Green Turtle (Chelonia mydas) in Vamizi Island, Mozambique. Springer Plus, 3, 540. https://doi.org/10.1186/2193-1801-3-540

[10] Anastácio, R., Lopes, C., Ferrão, J. and Pereira, M.J. (2017) Eretmochelys imbricata: Lessons to Learn from a Monitoring Program in the North of Mozambique. Natural Resources, 8, 382-396. https://doi.org/10.4236/nr.2017.85024

[11] da Silva, I.M., Hill, N., Shimadzu, H., Soares, A.M.V.M. and Dornelas, M. (2015) Spillover Effects of a Community-Managed Marine Reserve. PLoS ONE, 10, e0111774. https://doi.org/10.1371/journal.pone.0111774

[12] Hancke, L., Roberts, M.J. and Ternon, J.F. (2014) Surface Drifter Trajectories Highlight Flow Pathways in the Mozambique Channel. Deep-Sea Research II, 100, 27-37. https://doi.org/10.1016/j.dsr2.2013.10.014

[13] Hamann, M., Godfrey, M.H., Seminoff, J.A., Arthur, K., Barata, P.C.R., Bjorndal, K.A., Bolten, A.B., Broderick, A.C., Campbell, L.M., Carreras, C., Casale, P., Chaloupka, M., Chan, S.K.F., Coyne, M.S., Crowder, L.B., Diez, C.E., Dutton, P.H., Epperly, S.P., FitzSimmons, N.N., Formia, A., Girondot, M., Hays, G.C., Cheng, I.J., Kaska, Y., Lewison, R., Mortimer, J.A., Nichols, W.J., Reina, R.D., Shanker, K., Spotila, J.R., Tomás, J., Wallace, B.P., Work, T.M., Zbinden, J. and Godley, B.J. (2010) Global Research Priorities for Sea Turtles: Informing Management and Conservation in the 21st Century. Endangered Species Research, 11, 245-269. https://doi.org/10.3354/esr00279

[14] Ternon, J.F., Roberts, M.J., Morris, T., Hancke, L. and Backeberg, B. (2014) In Situ Measured Current Structures of the Eddy Field in the Mozambique Channel. Deep-Sea Research II, 100, 10-26. https://doi.org/10.1016/j.dsr2.2013.10.013

[15] Indian Ocean Turtle Newsletter (IOTN) (2010) https://www.iotn.org

[16] Hawkes, L.A., Broderick, A.C., Godfrey, M.H. and Godley, B.J. (2009) Climate Change and Marine Turtles. Endangered Species Research, 7, 137-154. https://doi.org/10.3354/esr00198

[17] Vilaça, S.T., Lara-Ruiz, P., Marcovaldi, M.A., Soares, L.S. and Santos, F.R. (2013) Population Origin and Historical Demography in Hawksbill (Eretmochelys imbricata) Feeding and Nesting Aggregates from Brazil. Journal of Experimental Marine Biology and Ecology, 446, 334-344. https://doi.org/10.1016/j.jembe.2013.06.004

[18] Putman, N.F. and Mansfield, K.L. (2015) Direct Evidence of Swimming Demonstrates Active Dispersal in the Sea Turtle "Lost Years". Current Biology, 25, 1221 1227. https://doi.org/10.1016/j.cub.2015.03.014

[19] Avise, J.C. (2007) Conservation Genetics of Marine Turtles-Ten Years Later. In: Hewitt, D. and Fulbright, T., Eds., Frontiers in Wildlife Science: Linking Ecological Theory and Management Application. CRC Press, Boca Raton, 295-314. https://doi.org/10.1201/9781420007619.ch17

[20] Lee, P.L.M. (2008) Molecular Ecology of Marine Turtles: New Approaches and Future Directions. Journal of Experimental Marine Biology and Ecology, 356, 25-42. https://doi.org/10.1016/j.jembe.2007.12.021

[21] Blumenthal, J.M., Abreu-Grobois, F.A., Austin, T.J., Broderick, A.C., Bruford, M.W., Coyne, M.S., Ebanks-Petrie, G., Formia, A., Meylan, P.A., Meylan, A.B. and Godley, B.J. (2009) Turtle Groups or Turtle Soup: Dispersal Patterns of Hawksbill 
Turtles in the Caribbean. Molecular Ecology, 18, 4841-4853. https://doi.org/10.1111/j.1365-294X.2009.04403.x

[22] Santos, C., Anastácio, R., Lopes, C., Ferrão, J., Souto, L. and Pereira, M. (2011) Phylogeography of Hawksbill Turtle (Eretmochelys imbricata) in the North of Mozambique Channel. GenBank, Unpublished.

[23] Levin, H.L. (2013) The Earth through Time. 10th Edition, John Wiley \& Sons Inc., Hoboken, 469 p.

[24] Spotila, J.R. (2004) Sea Turtles: A Complete Guide to Their Biology, Behavior and Conservation. The Johns Hopkins University Press and Oakwood Arts, Baltimore, Maryland, 57-69.

[25] Filippelli, G.M. and Flores, J.-A. (2009) From the Warm Pliocene to the Cold Pleistocene: A Tale of Two Oceans. Geology, 37, 959-960. https://doi.org/10.1130/focus102009.1

[26] Dodson, J. (2012) Climate Change through Time in Talent. In: de Mulder, E.F.J. Ed., Earth and Life, International Year of Planet Earth, Springer Science+Business Media, Berlin, 51-62.

[27] Graham, M.H., Dayton, P.K. and Erlandson, J.M. (2003) Ice Ages and Ecological Transitions on Temperate Coasts. Trends in Ecology and Evolution, 18, 33-40. https://doi.org/10.1016/S0169-5347(02)00006-X

[28] Fuentes, M.M.P.B., Limpus, C.J., Hamann, M. and Dawson, J. (2010) Potential Impacts of Projected Sea-Level Rise on Sea Turtle Rookeries. Aquatic Conservation: Marine and Freshwater Ecosystems, 20, 132-139. https://doi.org/10.1002/aqc.1088

[29] Bowen, B.W. and Karl, S.A. (2007) Population Genetics and Phylogeography of Sea Turtles. Molecular Ecology, 16, 4886-4907. https://doi.org/10.1111/j.1365-294X.2007.03542.x

[30] Benton, M.J. (2005) Vertebrate Palaeontology. 3rd Edition, Blackwell Publishing Company, Hoboken, 229-231.

[31] Avise, J.C., Bowen, B.W., Lamb, T., Meylan, A.B. and Bermingham, E. (1992) Mitochondrial DNA Evolution at a Turtle's Pace: Evidence for Low Genetic Variability and Reduced Microevolutionary Rate in the Testudines. Molecular Biology and Evolution, 9, 457-473.

[32] Vargas, S.M., Jensen, M.P., Ho, S.Y.W., Mobaraki, A., Broderick, D., Mortimer, J.A., Whiting, S.D., Miller, J., Prince, R.I.T., Bell, I.P., Hoenner, X., Limpus, C.J., Santos, F.R. and Fitzsimmons, N.N. (2016) Phylogeography, Genetic Diversity and Management Units of Hawksbill Turtles in the Indo-Pacific. Journal of Heredity, 107, 199-213. https://doi.org/10.1093/jhered/esv091

[33] Mohd Arshaad, W. and Syed Abdul Kadir, S.A. (2010) Identification of the Stock Population of Green and Hawksbill Turtles in the Southeast Asian Region. Eretmochelys imbricata Haplotype Ei_15 D-Loop, Partial Sequence; Mitochondrial. ACCESSION HM030866. GenBank, Unpublished https://www.ncbi.nlm.nih.gov/nuccore/295983958

[34] Nishizawa, H., Joseph, J. and Chong, Y.K. (2016) Spatio-Temporal Patterns of Mitochondrial DNA Variation in Hawksbill Turtles (Eretmochelys imbricata) in Southeast Asia. Journal of Experimental Marine Biology and Ecology, 474, 164-170. https://doi.org/10.1016/j.jembe.2015.10.015

[35] Nishizawa, H., Okuyama, J., Kobayashi, M., Abe, O. and Arai, N. (2010) Comparative Phylogeny and Historical Perspectives on Population Genetics of the Pacific Hawksbill (Eretmochelys imbricata) and Green Turtles (Chelonia mydas), Inferred 
from Feeding Populations in the Yaeyama Islands Japan. Zoological Science, 27, 1418. https://doi.org/10.2108/zsj.27.14

[36] Duchene, S., Frey, A., Alfaro-Núñez, A., Dutton, P.H., Gilbert, M.T.P. and Morin, P.A. (2012) Marine Turtle Mitogenome Phylogenetics and Evolution. Molecular Phylogenetics and Evolution, 65, 241-250. https://doi.org/10.1016/j.ympev.2012.06.010

[37] Avise, J.C. (2000) Phylogeography: The History and Formation of Species. Harvard University Press, Cambridge.

[38] Encalada, S.E., Lahanas, P.N., Bjorndal, K.A., Bolten, A.B., Miyamoto, M.M. and Bowen, B.W. (1996) Phylogeography and Population Structure of the Atlantic and Mediterranean Green Turtle Chelonia mydas: A Mitochondrial DNA Control Region Sequence Assessment. Molecular Ecology, 5, 473-483. https://doi.org/10.1111/j.1365-294X.1996.tb00340.x

[39] Reece, J.S., Castoe, T.A. and Parkinson, C.L. (2005) Historical Perspectives on Population Genetics and Conservation of Three Marine Turtle Species. Conservation Genetics, 6, 235-251. https://doi.org/10.1007/s10592-004-7821-y

[40] Rogers, A.R. and Harpending, H. (1992) Population Growth Makes Waves in the Distribution of Pairwise Population Differences. Molecular Biology and Evolution, 9, 552-569.

[41] Shanker, K., Ramadevi, J., Choudhury, B.C., Singh, L. and Aggarwal, R.K. (2004) Phylogeography of Olive Ridley Turtles (Lepidochelys olivacea) on the East Coast of India: Implications for Conservation Theory. Molecular Ecology, 13, 1899-1909. https://doi.org/10.1111/j.1365-294X.2004.02195.x

[42] Pilcher, N.J., Antonopoulou, M., Perry, L., Abdel-Moati, M.A., Al Abdessalaam, T.Z., Albeldawi, M., Al Ansi, M., Al-Mohannadi, S.F., Al Zahlawi, N., Baldwin, R., Chikhi, A., Sekhar Das, H., Hamza, S., Kerr, O.J., Al Kiyumi, A., Mobaraki, A., Al Suwaidi, H.S., Al Suweidi, A.S., Sawaf, M., Tourenq, C., Williams, J. and Willson, A. (2014) Identification of Important Sea Turtle Areas (ITAs) for Hawksbill Turtles in the Arabian Region. Journal of Experimental Marine Biology and Ecology, 460, 8999. https://doi.org/10.1016/j.jembe.2014.06.009

[43] US Department of Commerce U.S. National Oceanic and Atmospheric Administration (NOAA) and US Department of the Interior (2013) Hawksbill Sea Turtle (Eretmochelys imbricata) 5-Year Review: Summary and Evaluation. National Marine Fisheries Service Office of Protected Resources Silver Spring, Maryland and U.S. Fish and Wildlife Service Southeast Region Jacksonville Ecological Services Office Jacksonville.

http://www.nmfs.noaa.gov/pr/pdfs/species/hawksbillseaturtle2013_5yearreview.pdf

[44] Tabib, M., Zolgharnein, H., Mohammadi, M., Salari-Aliabadi, M.A., Qasemi, A., Roshani, S., Rajabi-Maham, H. and Frootan, F. (2011) mtDNA Variation of the Critically Endangered Hawksbill Turtle (Eretmochelys imbricata) Nesting on Iranian Islands of the Persian Gulf. Genetics and Molecular Research, 10, 1499-1503. https://doi.org/10.4238/vol10-3gmr1148

[45] Tabib, M., Frootan, F. and Hesni, M.A. (2014) Genetic Diversity and Phylogeography of Hawksbill Turtle in the Persian Gulf. Journal of Biodiversity and Environmental Sciences, 4, 51-57. www.innspub.net

[46] Mohd Arshaad, W. and Syed Abdul Kadir, S.A. (2010) Eretmochelys Imbricata Haplotype Ei_1 D-Loop, Partial Sequence; Mitochondrial. https://www.ncbi.nlm.nih.gov/nuccore/HM030865.1

[47] Putman, N.F., Abreu-Grobois, F.A., Broderick, A.C., Ciofi, C., Formia, A., Godley, 
B.J., Stroud, S., Pelembe, T., Verley, P. and Williams, N. (2014) Numerical Dispersal Simulations and Genetics Help Explain the Origin of Hawksbill Sea Turtles in Ascension Island. Journal of Experimental Marine Biology and Ecology, 450, 98-108. https://doi.org/10.1016/j.jembe.2013.10.026

[48] Monzón-Argüello, C., Loureiro, N.S., Delgado, C., Marco, A., Lopes, J.M., Gomes, M.G. and Abreu-Grobois, F.A. (2011) Príncipe Island Hawksbills: Genetic Isolation of an Eastern Atlantic Stock. Journal of Experimental Marine Biology and Ecology, 407, 345-354. https://doi.org/10.1016/j.jembe.2011.07.017

[49] Lara-Ruiz, P., Lopez, G.G., Santos, F.R. and Soares, L.S. (2006) Extensive Hybridization in Hawksbill Turtles (Eretmochelys imbricata) Nesting in Brazil Revealed by mtDNA Analyses. Conservation Genetics, 7, 773-781.

https://doi.org/10.1007/s10592-005-9102-9

Submit or recommend next manuscript to SCIRP and we will provide best service for you:

Accepting pre-submission inquiries through Email, Facebook, LinkedIn, Twitter, etc. A wide selection of journals (inclusive of 9 subjects, more than 200 journals)

Providing 24-hour high-quality service

User-friendly online submission system

Fair and swift peer-review system

Efficient typesetting and proofreading procedure

Display of the result of downloads and visits, as well as the number of cited articles

Maximum dissemination of your research work

Submit your manuscript at: http://papersubmission.scirp.org/

Or contactnr@scirp.org 